\title{
AUTOREGRESSIVE DISTRIBUTED LAG MODELING OF THE EFFECTS OF SOME MACROECONOMIC VARIABLES ON ECONOMIC GROWTH IN NIGERIA
}

\section{Monday Osagie ${ }^{1,2}$ Adenomon \& Rotimi Olalekan ${ }^{1}$ Ojo}

\author{
1. NSUK-LISA Stat Lab \\ 1. Department of Statistics, Nasarawa State University, Keffi, Nigeria \\ 2. Foundation of Laboratory for Econometrics and Applied Statistics of Nigeria (aka \\ FOUND-LEAS-IN-NIGERIA) \\ adenomonmo@nsuk.edu.ng ojo.rotimi2011@ gmail.com \\ Tel: $+2347036990145 ;+2348066717363$
}

2. https://orcid.org/0000-0002-9523-8032

\begin{abstract}
Research background: Relationship between inflation rate, unemployment rate, interest rate and real gross domestic product per capita in Nigeria. However, there seems to be a short-run or long-run relationship among the macroeconomic variables.

Purpose: This study investigated the impact of the inflation rate, unemployment rate and interest rate on real gross domestic product per capita (RGDPPC) (proxy for economic growth) and proffered recommendations towards enhancing economic growth and to reduce the distasteful effects of inflation rate, unemployment rate and interest rate in Nigeria in this present time economic challenges.

Research methodology: This study applied a linear dynamic model Autoregressive Distributed Lag (ARDL) modeling technique to analyze the short-run dynamics and long-run relationship of the economic growth in Nigeria over the sample period between 1984 and 2017 using annual secondary data extracted from World Bank Development Indicators Report (last updated January 2019).

Results: The empirical results showed that there was long-run relationship between inflation rate, unemployment rate and interest rate on real gross domestic product per capita (proxy for economic growth) in Nigeria. The result further revealed that only unemployment rate had a significant positive impact on real gross domestic product per capita in the long-run and inflation rate had a significant negative impact on real gross domestic product per capita in the short-run. Novelty: Therefore, the study concluded that unemployment rate and inflation rate proved to have significant impacts on economic growth in the long-run and short-run respectively. Formulation of policies to reduce unemployment through the adoption of labour concentrated technique of production, entrepreneurship development and policy to keep the inflation rate at single digit.
\end{abstract}

Keywords: ARDL, Inflation, Interest, Long-run, RGDPPC, Short-run, Unemployment

JEL Classification: J21, P43 


\section{Introduction}

The ultimate goal of different measures of economic growth is to provide a report card for government to see how their economy is doing and measure economic performance at the instance or over time. Real gross domestic product per capita (RGDPPC) as one of the measures for economic growth is defined as the average of individual incomes in the economy adjusted for inflation i.e. taking real gross domestic product (GDP) and dividing it by the population (Jim, 2019). The relationship between economic growth and macroeconomic variables (determinants) has long been a trendy issue of discussions in the literature of economic development (Nihat, et al. 2013). Research on economic growth being undertaken in both theoretical and applied work, focuses on macroeconomic policies to achieve stable prices (low inflation), low levels of debt (both foreign and domestic), free market economy, low rate of unemployment and an open economy (Mbulawa, 2015).

Unemployment remains one of the major macroeconomic problems to a significant number of nations. The problem of unemployment is peculiar and on the increase in developing countries as a result of different economic problems facing most of them. National Bureau of statistics (NBS) defines unemployment in Nigeria as the percentage of labour force that was available for work but did not work in the week prior to the survey period for at least 39hours. Feridun and Akindele (2006) recognised unemployment as one of the prime challenges the Nigerian economy is faced with. The social impacts and societal vices resulting from unemployment are less established in economies with programmes like subsidies and social security allowances to support the unemployed class (Olawunmi and Adebayo, 2017). Udabah (1999) identified a key rationale for low standard of living amongst underdeveloped countries as the relative scarce, unproductive and ineffective exploitation of labour compared with developed nations. Fadayomi (1992), Osinubi (2006), contended that unemployment is created from the inability to create and satisfactorily use the nation' s labor assets particularly within the rural sector. Since the alter in administration from military to democratic show of government in 1999, the major approach of the government and international organisations is focused on at lessening the rate of unemployment within the 21 st century, in order to devoid the nation of more dangerous acts than existing ones (Olawunmi and Adebayo, 2017). 
On the other hand, inflation can be defined as a significant and continuous increase in the general price level over a period of time (James, 2019). Periods of high inflation, translates to the diminishing value of the domestic currency which impacts on the economy negatively (Folorunso and Abiola, 2000). The problem of inflation surely is not a new occurrence because it has remained a major problem in the country over the past few years. Within the words of Adenuga, et al. (2012), it may be a creature which undermines all economies because of its inconvenient impacts. Effort by the government of Nigeria to curb the increase in unemployment and rising price level, has seen the formulation of several macroeconomic policies geared towards economic growth with regards to interest rate, exchange rate and inflation rate been the central focus of the policy makers and their development partners (Jelilov et al. 2016).

In spite of the fact that, with a few positive impacts on economic growth, interest rate has remained exceedingly high with overpowering effect which has taken a toll on borrowing and investment in Nigeria, which has been the bane of disheartening for foreign investment (Hakkio, 2000). Inyiama (2013) studied the link among inflation, interest and exchange rates on economic growth in Nigeria. Utilising the ordinary least square method to a data set of 1979-2010 for each of the variables, a multiple regression was adopted. It was established that inflationary rate is negatively related with real gross domestic product while a positive relationship existed for exchange rates and interest rates though not significant. However, the impacts of expanding interest rate on the economic growth of Nigeria have remained questionable (Acha, 2011). This research therefore examines the extent of impact to which macroeconomic variables like inflation rate (INFR), unemployment rate (UNEMR), and interest rate (INTR) have on real gross domestic product per capita (RGDPPC) (proxy for economic growth) in Nigeria in the $20^{\text {th }}$ through to the $21^{\text {st }}$ century. The following sections are literature reviews, research methods, analysis, and discussion of the results, conclusion and recommendation.

\section{Literature Review}

The investigation of the impact of inflation rate on economic growth in Nigeria between the periods 1970 to 2011 showed a bi-directional relationship between inflation rate and economic growth in the economy (Osuala, et al., 2013). Real gross domestic product (RGDP) and inflation rate are the variables used in the study. More so, Umaru \& Zubairu (2012) carried out a similar study on the impact of inflation rate on economic development in Nigeria using data from the 
year 1970 to 2010 while testing for stationarity and causality. All variables were stationary at first difference and gross domestic product (GDP) granger caused inflation as revealed by the result. Following the result of no co-integration (no long-run relationship) between inflation and economic growth; a high correlation coefficient established a strong relationship between inflation and gross domestic product (GDP) (proxy for economic growth) in Tanzania between the period 1990 to 2011 as examined by Kasidi and Mwakanemela in 2013. The results also displayed a negative impact of inflation on economic growth in Tanzania. Aminu \& Anono (2012) employed the use of Augmented Dickey Fuller (ADF) test, Ordinary Least Square (OLS) technique and Granger causality to study the effect of inflation on economic growth and development in Nigeria using macroeconomic data from 1986 to 2011. An insignificant positive relationship between inflation rate and economic growth in Nigeria was disclosed. Unidirectional relationship between gross domestic product (GDP) and inflation rate was revealed from the result of the granger causality test.

Several studies have been carried out to examine the relationship between economic growth and unemployment. However, different results were obtained due to the econometric techniques, countries researched, data and period of the study used. Okun's Law expresses a positive relationship between economic growth and employment or a negative relationship between economic growth and unemployment rate. This law simply put, say that a one percent (1\%) increase in gross domestic product (GDP) will result in a 0.3-0.5 percent decrease in unemployment (Meyer \& Tasci, 2012). Globally, an economy with relative low economic growth condition finds it difficult and slow to achieve creation of new jobs. On one hand, both the creation and protection of jobs are required to guarantee income and wealth creation and on the other hand, rising levels of unemployment leads to socioeconomic problems (Kitov \& Kitov, 2011). Onwachukwu (2015) examined the time series data from 1985 to 2010 for macroeconomic variables real gross domestic product (RGDP), inflation rate and unemployment rate in Nigeria. The study employed Augmented Dickey Fuller technique and the ordinary least squares (OLS). The result showed a significant and an insignificant negative effect of unemployment rate and inflation rate on economic growth in the economy of Nigeria. The negative impact of unemployment and inflation rate on economic growth in Nigeria is in line with the empirical findings from the studies of Bakare (2012) and Ogueze and Odim (2015). 
Mostly, all economies intend to maintain as low as possible both inflation and unemployment rate and it is targeted on a single-digit rate as it is likely to bring about stability in macroeconomic policies of the country. The stable state of the macroeconomic policies is essential to realise its set goals and objective which is effective growth and development in the economy (Orji et al., 2015). Undoubtedly, increase in the level of production of goods and services bring about social harmony and an improved standard of living as desired by the citizens within the country. Inconsistencies in the Real Gross Domestic Product (RGDP) have resulted to irregular inflation rate in the economy of Nigeria in recent years (Jelilov and Obasa, 2016). Ademola and Badiru (2016) in a most recent study adopted the use of ordinary least squares (OLS) technique with some diagnostic tests to examine the effects of inflation rate and unemployment rate on economic growth performance from 1981 to 2014 in Nigeria. The result from the study indicates that inflation and unemployment rate are positively related to economic growth in Nigeria. Aminu, et al,. (2013) looked at the combined impact of inflation rate and unemployment rate on the economic development in Nigeria from 1986 to 2010 by employing similar techniques as Inyiama in the year 2013. The Augmented Dickey Fuller test presented all variables stationary at first difference I(1). Long-run relationship between economic growth, inflation and unemployment rate was revealed from the results of the Johansen co-integration test. The Granger causality test result revealed that unemployment and inflation granger causes real gross domestic product (RGDP) in the economy of Nigeria.

The focus of monetary policy is on the relationship of the total supply of money in an economy and the price at which the supplied money can be borrowed. This relationship could be expansionary or contractionary. Expansionary monetary policy refers to the swift increase in the total supply of money in the economy, and contractionary monetary policy decreases the total money supply in the economy, or increases it gradually (Essien et al., 2016). For the purpose of decreasing unemployment, the Central Bank embarks on an expansionary monetary policy which excites the domestic economy, while increasing interest rates aims at mitigating the effect of inflation when contractionary monetary policy is adopted (Engler, 2011). (Altavilla and Ciccarelli, 2009) premised that with the uncertain nature of the relationship between interest rate and unemployment rate, it has been established and generally accepted that there is a significant impact of monetary policy on domestic economic activities and employment. Saymeh and Orabi (2013) investigated the effect of interest rate, inflation rate and GDP on macroeconomic growth 
in Jordan over the period 2000-2010. From the Johansen test performed, it revealed that all four equations had significant existence at $1 \%$ or $5 \%$ for the trace and max eigen value static. It was therefore concluded that a long term equilibrium relationship existed among variables. Granger Causality results showed that only inflation causes interest rate while others are independent, hence no causality. However, regression results to check for impacts of both inflation and interest rate on growth rate found that inflation has significant effect on growth rate while only prevailing interest rate has significant influence on growth rate.

\section{Research Method}

\subsection{Data}

For the study of the impact of inflation rate, unemployment rate and interest rate on real gross domestic product per capita (proxy for economic growth) in Nigeria, an autoregressive distributed lagged modeling technique was employed to study time series data over a thirty four (34) year period from 1984 to 2017. The Autoregressive Distributed Lagged (ARDL) model enables the dependent variable to be explained by the independent variables and their lags; and also its own lag. Data on inflation, unemployment and interest are expressed in percentages while data on real gross domestic product per capita is expressed in value. All data were extracted from the World Bank Development Indicators Report (Last updated 30/01/2019) except data on unemployment rate which was extracted from National Bureau of Statistics (2019). Inflation was measured as the annual percentage change in the cost to the average consumer of acquiring a basket of goods and services that may be fixed or changed at specified intervals, such as yearly. The unemployment rate was measured as the percentage of the active labour force that were willing to work and looking for job but without a job to total active labour force in the population. Interest rate was measured as the lending bank rate that usually meets the short-term and medium-term financing needs of the private sector. Real gross domestic product per capita was measured as gross domestic product at purchaser's prices divided by mid-year population, which is the sum of gross value added by all resident producers in the economy plus any product taxes and minus any subsidies not included in the value of the products. It is calculated without making deductions for depreciation of fabricated assets or for depletion and degradation of natural resources. Data are in constant local currency. The required ARDL model, 
pre-estimation and post-estimation diagnostics techniques necessary for taking decisions and arriving at a satisfactory conclusion is specified below.

\subsection{Model Specification}

Autoregressive Distributed Lag Model (ARDL) model plays a key role when faced with making vital economic decision from past data. Change in economic variables may bring change in other economic variables beyond the time (Kripfganz and Schneider, 2018). This is termed as changes distributed over future periods. This is a model containing the lagged values of the dependent variable, the current and lagged values of the regressors as explanatory variables. The ARDL model uses a combination of endogenous and exogenous variables. It is often necessary for stationary (unit root) test to be conducted to ascertain that no variable is integrated of order 2 i.e. I(2). The ARDL model can be specified if the variables are integrated of different orders. That is, a model having a combination of variables with $\mathrm{I}(0)$ i.e. level stationary variables and I(1) i.e. $1^{\text {st }}$ difference stationary variables order of integration (Nkoro and Uko, 2016). ARDL model can also be used if all the variables are integrated of order one i.e. stationary after first difference $\mathrm{I}(1)$. The general model of the $\operatorname{ARDL}(p, q)$ is as follows:

$$
y_{t}=\varphi+\sum_{i=1}^{p} \alpha_{i} y_{t-i}+\sum_{i=0}^{q} \beta_{i} x_{t-i}+\varepsilon_{t}
$$

Or broken down as:

$$
y_{t}=\varphi+\alpha_{1} y_{t-1}+\cdots+\alpha_{p} y_{t-p}+\beta_{0} x_{t}+\beta_{1} x_{t-1}+\beta_{2} x_{t-2}+\cdots+\beta_{q} x_{t-q}+\varepsilon_{t}
$$

Where:

$y_{t}:$ Dependent variable $\left(\right.$ RGDPPC $\left._{\mathrm{t}}\right)$

$y_{t-i}:$ Lag of the dependent variable $\left(\mathrm{RGDPPC}_{\mathrm{t}-\mathrm{i}}\right)$

$x_{t}$ : Independent variable (INFR $\left., \mathrm{UNEMR}_{\mathrm{t}}, \mathrm{INTR}_{\mathrm{t}}\right)$

$x_{t-i}:$ Lag of the independent variable $\left(\right.$ INFR $\left._{\mathrm{t}-\mathrm{i}}, \mathrm{UNEMR}_{\mathrm{t}-\mathrm{i}}, \mathrm{INTR}_{\mathrm{t}-\mathrm{i}}\right)$

$p$ : Optimal lag order associated with the dependent variable in years

$q$ : Optimal lag order associated with the independent variable in years 
$\varphi:$ Constant

$\alpha_{i}$ : Coefficient for dependent variable (coefficients for short-run)

$\beta_{i}$ : Coefficient for Independent variable (coefficient for long-run)

$\varepsilon_{t}:$ Error Term

Variables used to assess the significance of the relationship between the macroeconomic variables and the economic growth of Nigeria, are in their natural log form. The growth model can be represented mathematically as:

$$
L N R G D P P C=f(L N I N F R, L N U N E M R, L N I N T R)
$$

The linear relationship of equation (3) could be stated as:

$$
\ln (R G D P P C)=\varphi+\beta_{1} \ln (I N F R)+\beta_{2} \ln (U N E M R)+\beta_{3} \ln (I N T R)+\varepsilon
$$

Where RGDPPC (Real gross domestic product per capita) is the dependent variable, $\varphi$ is the intercept term, $\beta_{1}$ is the coefficient of INFR (Inflation rate) (independent variable), $\beta_{2}$ is the coefficient of UNEMR (Unemployment rate) (independent variable), $\beta_{3}$ is the coefficient of INTR (Interest rate) (independent variable) and $\varepsilon$ is the unexplained part of the actual data and fitted line by regression equation known as the error term.

\subsection{Pre-Estimation Tests}

Pre-estimation test are parametric test carried out on the time series data to meet the assumptions of the model to be estimated. The pre-estimation tests are normality test (Jarque-Bera test), stationarity test (Augmented Dicker Fuller test), co-integration test (ARDL Bounds test) and optimal lag length determination.

\section{Normality Test (Jarque-Bera Test)}

The basic assumption that sampled data are normally distributed is what many methods of time series analysis depend on (Thode, 2002). This assumption is very vital for the reliability of parametric tests results.

Stationary Test (Augmented Dicker Fuller) (ADF) 
Time series data is said to be stationary when its value tends to revert to its long-run average value and its other properties like the variance and co-variance of the data series are not affected by the change in time (i.e. time invariant) (Shrestha and Bhatta, 2018). The most common method for testing unit root for parametric analyses is the Augmented Dickey Fuller (ADF) test. Let' $s$ assume we have a series $y_{t}$ for testing unit root. ADF model tests unit root as follows:

$$
\Delta \mathrm{y}_{\mathrm{t}}=\mu+\delta \mathrm{y}_{\mathrm{t}-1}+\sum_{\mathrm{i}=1}^{\mathrm{k}} \beta_{\mathrm{i}} \Delta \mathrm{y}_{\mathrm{t}-\mathrm{i}}+\varepsilon_{\mathrm{t}}
$$

Where:

$\delta=\alpha-1$

$\alpha=$ coefficient of $\mathrm{y}_{\mathrm{t}-1}$

$\Delta y_{t}=$ First difference of $y_{t}$ i.e. $y_{t}-y_{t-1}$

The hypothesis of ADF is

$\mathrm{H}_{\mathrm{o}}: \delta=0$ (There is unit root, i.e. the series is non-stationary) vs.

$\mathrm{H}_{1}: \delta<0$ (There is no unit root, i.e. the series is stationary)

If we do not reject the null hypothesis, the series is non-stationary otherwise the series is stationary.

\section{Co-integration Test (ARDL Bounds Test)}

There is co-integration between two or more variables if there exist a form of equilibrium relationship spanning the long-run (Shrestha and Bhatta, 2018). The Bounds test is guided by the assumption of stationary variables at level $\mathrm{I}(0)$, at first difference $\mathrm{I}(1)$ and never at second difference I(2) (Giles, 2013). To perform the bounds test for co-integration, the conditional ARDL $\left(p, q_{1}, q_{2}, q_{3}\right)$ model with 4 variables. This will be the hypothesis for the bounds test:

$$
\begin{aligned}
& H_{0}: b_{j i}=0 \quad \text { where } j, i=1,2,3,4 \\
& H_{1}: b_{j i} \neq 0
\end{aligned}
$$


i.e. The null hypothesis is saying that the coefficient of the long-run equation are all equal to zero which implies there is no co-integration against the alternative hypothesis which say the coefficient of the long-run equation are all not equal to zero, which implies there is cointegration. If we are unable to reject the null hypothesis then we can only specify the short-run model otherwise we go ahead to specify a standard ARDL model. If there is no co-integration, the ARDL $\left(p, q_{1}, q_{2}, q_{3}\right)$ models will be specified as:

$$
\begin{aligned}
& \Delta \ln R G D P P C_{t}=a_{01}+\sum_{i=1}^{p} a_{1 i} \Delta \ln R G D P P C_{t-i}+\sum_{i=0}^{q_{1}} a_{2 i} \Delta \ln I N F R_{t-i}+ \\
& \sum_{i=0}^{q_{2}} a_{3 i} \Delta \ln U N E M R_{t-i}+\sum_{i=0}^{q_{3}} a_{4 i} \Delta \ln I N T R_{t-i}+\varepsilon_{t}
\end{aligned}
$$

If there is co-integration, the error correction model (ECM) representation is specified as:

$$
\begin{aligned}
& \Delta \ln R G D P P C_{t}=a_{01}+\sum_{i=1}^{p} a_{1 i} \Delta \ln R G D P P C_{t-i}+\sum_{i=0}^{q_{1}} a_{2 i} \Delta \ln I N F R_{t-i}+ \\
& \sum_{i=0}^{q_{2}} a_{3 i} \Delta \ln U N E M R_{t-i}+\sum_{i=0}^{q_{3}} a_{4 i} \Delta \ln I N T R_{t-i}+\lambda E C T_{t-1}+\varepsilon_{t}
\end{aligned}
$$

where:

i. $\lambda=$ speed of adjustment parameter with a negative sign which shows convergence in the long-run else the model is explosive

ii. $E C T=$ the error correction term, the ordinary least squares (OLS) residuals series from the long-run co-integrating regression

iii. $a_{1 i}, a_{2 i}, a_{3 i}, a_{4 i}$ are the short-run dynamic coefficient of the model' s adjustment long-run equilibrium

Where we have the differences $(\Delta)$, it captures the short-run and where we have the ECT, it captures the long-run. The short-run causal effect is represented by the statistical significance of the t-statistic on the explanatory variables (short-run coefficients). If the t-statistic of the coefficients $a_{1 i}, a_{2 i}, a_{3 i}, a_{4 i}$ is significant, then we can know the direction of causality from the regressor to the dependent variable (Giles, 2013). The long-run causal effect is captured by the 
significance of the $\lambda$, which is the parameter for the error correction term (ECT). If $\lambda$ is significant then it tells us that there is long-run causality among the variables.

\section{Optimal Lag Length Determination}

The choice of appropriate lag length is very key in autoregressive modeling because we want to have Gaussian error terms (i.e. standard normal error terms that do not suffer from nonnormality, autocorrelation, heteroscedasticity etc.) (Nkoro and Uko, 2016). The selection of optimal number of lags can be determined using proper model order selection criteria such as the Akaike Information Criterion (AIC), Schwartz Bayesian Criterion (SBC) or Hannan-Quinn criterion (HQC). The value of the general $\operatorname{ARDL}\left(p, q_{1}, q_{2}, \ldots . q_{k}\right)$ model is given by:

$$
\begin{aligned}
& A I C_{p}=(1+\log 2 \pi)-n / 2 \log \delta^{2}-P \\
& S B C_{p}=\log \left(\delta^{2}\right)+(\log n / n) P \\
& H Q C=\log \delta+(2 \log \log n / n) P
\end{aligned}
$$

Where $\delta^{2}$ is the Maximum Likelihood (ML) estimator of the variance of the regression disturbance, $n$ is the number of estimated parameters and $p=0,1,2 \ldots \ldots$, where $\mathrm{P}$ is the optimum order of the model selected (Nkoro and Uko, 2016).

\subsection{Post Estimation Tests}

\section{Autocorrelation Test}

One of the assumptions of the classical model is that the disturbance term relating to any observation is not influenced by the disturbance term relating to any other observation; however, if there is such dependence, there exist autocorrelation Gujarati (2005). Symbolically

$$
E\left(\varepsilon_{i}, \varepsilon_{j}\right) \neq 0
$$


With the advantages of the Breush-Godfrey test (also known as the LM test) over the Durbinwatson d test, we shall employ the use of the Breush-Godfrey test to check for the presence of autocorrelation in our disturbance term in this study.

\section{Heteroscedasticity Test}

An important assumption of the classical linear regression model is that the variance of each disturbance term $\varepsilon_{i}$, conditional on the chosen values of the explanatory variables, is some constant number equal to $\sigma^{2}$ Gujarati (2005). This assumption is known as homoscedasticity or equal variance. Symbolically,

$$
E\left(u_{i}^{2}\right)=\sigma^{2} \quad i=1,2, \ldots \ldots n
$$

For the purpose of this study, we shall be employing the Breusch-Pagan-Godfrey test to check for heteroscedasticity in our disturbance term.

\section{Normality Test for Residuals (Histogram and Jarque-Bera Test)}

In order to ensure that our model satisfies the assumption of classical normal linear regression model, it is important to check one of the assumptions known as the normality of the disturbance term, $\varepsilon_{i}$. The Jarque-Bera (JB) test of normality is an asymptotic test based on OLS residuals. It computes the skewness and kurtosis measures of the OLS residuals and uses the following test statistic:

$$
J B=n\left[\frac{S^{2}}{6}+\frac{(k-3)^{2}}{24}\right]
$$

Where:

$n=$ sample size

$S=$ skewness coefficient

$k=$ kurtosis coefficient 
The null hypothesis states that the residuals are normally distributed. If the p-value of the JB statistic in the application is sufficiently low, which can occur if the value of the statistic is very different from zero, one can reject the hypothesis that the residuals are normally distributed but with a reasonably high p-value, which will occur if the value of the statistic is close to zero, we do not reject the normality assumption (Gujarati, 2004).

\section{Parameter Stability Test (CUSUM Graph)}

The check for the stability of the estimated parameters from the regression model in the study is an important post-estimation check. Cumulative Sum (CUSUM) test is employed to help check if the coefficients of the regression are changing systematically or changing suddenly respectively (Bhatti et al. 2004). The Hypothesis is:

$H_{0}$ : Parameters are stable (which is desirable)

$H_{1}$ : Parameters are not stable (which is not desirable)

The decision rule state that if we find the blue line between or within the red line in our CUSUM, we accept the null hypothesis $\left(H_{0}\right)$ and reject the alternative hypothesis $\left(H_{1}\right)$. Alternatively, if the blue line crosses the red line in our CUSUM graph, we reject the null hypothesis $\left(H_{0}\right)$ and accept the alternative hypothesis $\left(H_{1}\right)$.

\section{Analysis and Discussion of the Results}

\subsection{Graphical Representation}

The graph represents a glance of the downward and upward movement of the individual variables with time. It is an indication of the increase or decrease of the effect of the selected macroeconomic variables within the study period.

Figure 1. Graphical Representations of Macroeconomic Variables (1984 - 2017) 


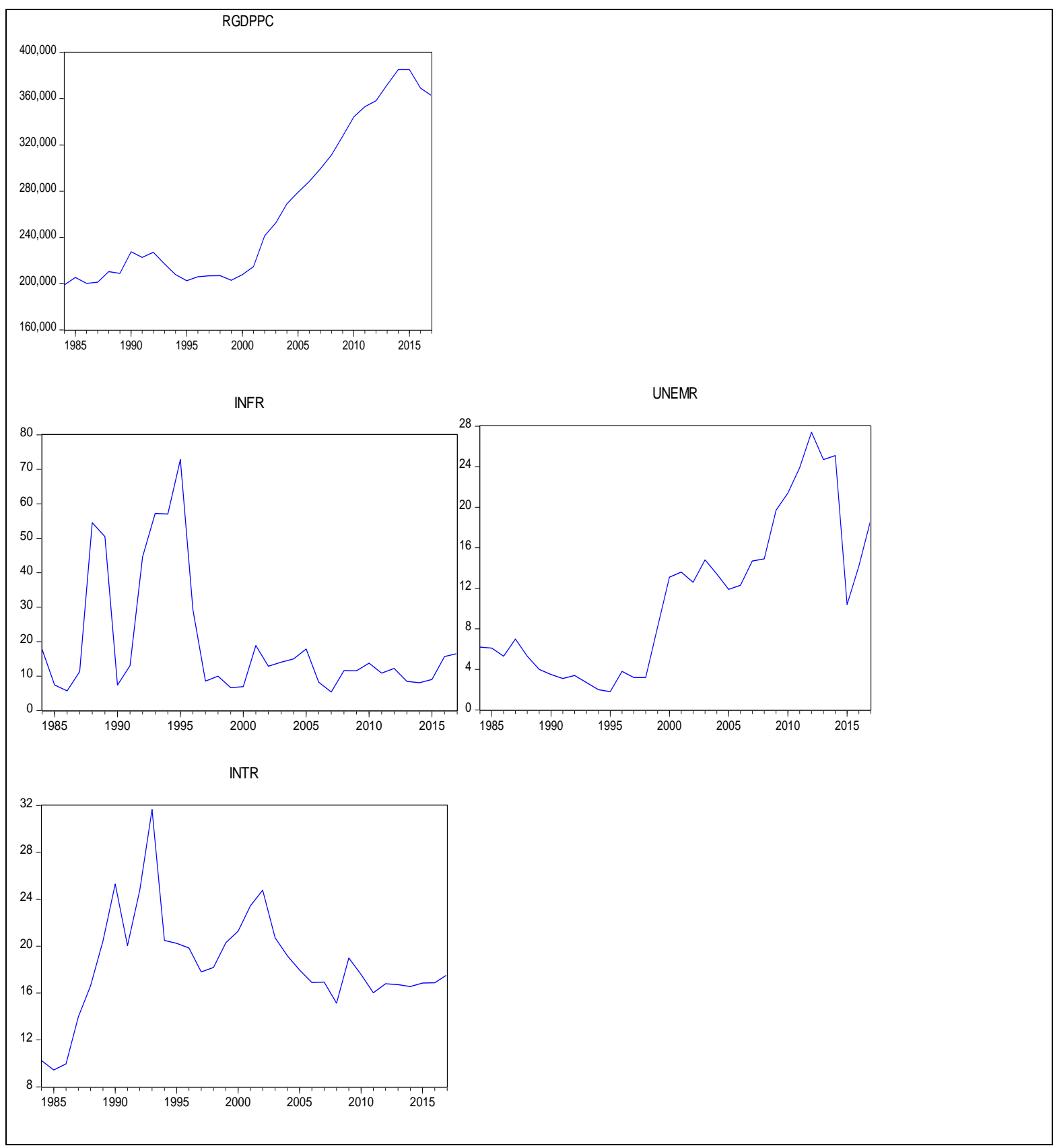

\subsection{Determination of Optimal Lag Length}

For annual data, one or two lags usually suffice for the determination of optimal lag length (Jeffrey, 2012). The outcomes of the optimal lag length determination from lag one (1) and lag two (2) and their corresponding Akaike information criterion (AIC), Schwarz Criterion (SC), Hannan-Quinn Criterion values and selected ARDL models are presented in table 1. The decision for the selection of the optimal lag length lies on the lag length with the minimum AIC 
value. From the result, the autoregressive distributed lag order of two (2) is selected based on the minimum AIC value of -4.265036 .

Table 1. ARDL Method of Optimal Lag Length Selection

\begin{tabular}{|l|l|l|l|l|}
\hline Lag length & $\begin{array}{l}\text { Akaike } \\
\text { Information } \\
\text { Criterion }\end{array}$ & Schwarz Criterion & $\begin{array}{l}\text { Hannan-Quinn } \\
\text { Criterion }\end{array}$ & $\begin{array}{l}\text { Selected ARDL } \\
\text { Model }\end{array}$ \\
\hline $\mathbf{1}$ & -4.265036 & -3.947595 & -4.158226 & $(1,1,1,0)$ \\
\hline $\mathbf{2}$ & -4.265036 & -3.947595 & -4.158226 & $(1,1,1,0)$ \\
\hline
\end{tabular}

Source: authors' computation (2019)

\subsection{Stationary Test (Augmented Dickey Fuller Test) ADF Test}

The estimation results of the unit root test through the application of the Augmented DickeyFuller (ADF) stationarity test at 5\% critical value is shown in table 2 below. The estimation results revealed that all the variables i.e. RGDPPC, INFR, UNEMR and INTR were not stationary at level; and yet, became stationary after first differencing at $5 \%$ critical value. This claim is supported by the ADF statistic values, critical values and p-values of the respective variables estimated in the test.

Table 2. Augmented Dickey-Fuller (ADF) Unit Root Test

\begin{tabular}{|l|l|l|l|l|l|l|l|l|l|}
\hline \multicolumn{9}{|c|}{ At Level } & \multicolumn{5}{c|}{ At First Difference } \\
\hline Variable & $\begin{array}{l}\text { ADF } \\
\text { Statistic }\end{array}$ & $\begin{array}{l}\text { Critical } \\
\text { Value } \\
\mathbf{5 \%}\end{array}$ & Prob. & Remark & Variable & ADF Statistic & $\begin{array}{l}\text { Critical } \\
\text { Value (5\%) }\end{array}$ & Prob. & Remark \\
\hline RGDPPC & 1.284480 & -1.952473 & 0.9460 & $\mathbf{N}$ & RGDPPC & -3.400208 & -1.951687 & 0.0013 & S \\
\hline INFR & -0.714494 & -1.951332 & 0.3995 & $\mathbf{N}$ & INFR & -3.717547 & -1.953381 & 0.0006 & S \\
\hline UNEMR & 0.237397 & -1.951332 & 0.7489 & N & UNEMR & -5.240932 & -1.951687 & 0.0000 & S \\
\hline INTR & -0.102704 & -1.952910 & 0.6398 & N & INTR & -2.798068 & -1.954414 & 0.0071 & S \\
\hline
\end{tabular}

\section{N: (Non-stationary) S: (Stationary)}

Source: author' s computation (2019) 


\subsection{Bound Testing}

The ARDL Bound test for Co-integration compares the F-statistic value to the upper I(1) and lower I(0) critical bound values as shown in table 3 below to determine the existence of cointegration among the variables. There exist no presence of co-integration among the variables if the F-statistic is less than the lower critical bound $\mathrm{I}(0)$, there is co-integration if the F-statistic value is greater than the upper critical bound I(1) and the result is inconclusive if the F-statistic value falls in between the lower I(0) and upper I(1) bound critical value. For this study, the Fstatistic value is greater than the upper critical bound value at all the significance level, and thus, it was concluded that there exists a unique long-run relationship among the variables.

Table 3. ARDL Bounds Test For Co-integration

\begin{tabular}{|c|c|c|}
\hline Test Statistics & Value & K \\
\hline F-Statistics & 8.769639 & 3 \\
\hline \multicolumn{3}{|c|}{ Critical Value Bounds } \\
\hline Significance & $\mathbf{I}(\mathbf{0})$ & $\mathbf{I}(\mathbf{1})$ \\
\hline $\mathbf{1 0 \%}$ & 2.72 & 3.77 \\
\hline $\mathbf{5 \%}$ & 3.23 & 4.35 \\
\hline $\mathbf{2 . 5 \%}$ & 3.69 & 4.89 \\
\hline $\mathbf{1 \%}$ & 4.29 & 5.61 \\
\hline
\end{tabular}

Source: authors' computation (2019).

\subsection{Result of the ARDL Estimation}

Table 4 shows the result of the ARDL model which allows the simultaneous estimation of the short-run and long-run coefficients of the model. With the discovery of long-run relationship among the variables, the study proceeds with estimating ARDL model to investigate the long-run relationship and short-run dynamics among real gross domestic product per capita (RGDPPC) (proxy economic growth) and its focus variables which are inflation rate (INFR), unemployment 
rate (UNEMR) and interest rate (INTR). The estimation results indicated that the coefficient value of inflation rate (INFR) is -0.013450 with its associated p-value being 0.1271 , which implies that inflation rate has negative and insignificant impact on real gross domestic product per capita (RGDPPC) in Nigeria in the short-run. More so, the coefficient value of unemployment rate (UNEMR) is 0.011401 while its p-value is 0.4805 . The result indicates that unemployment rate have positive and insignificant impact on real gross domestic product per capita (RGDPPC) also in the short-run. Furthermore, the coefficient value of interest rate (INTR) is 0.036735 with its p-value being 0.1200 , which implies that the interest rate (INTR) has positive and insignificant impact on real gross domestic product per capita (RGDPPC) in Nigeria in the long-run. The estimation results indicated that the coefficient value of unemployment rate (UNEMR) is 0.430299 with its associated p-value being 0.0000 , which implies that unemployment rate has positive and significant impact on real gross domestic product per capita (RGDPPC) in Nigeria in the long-run. The adjusted R-Square revealed that $98.83 \%$ variation in the real gross domestic product per capita is accounted for by the variations in inflation rate, unemployment rate and interest rate. The F-statistic value of 451.5096 with p-value of 0.0000 revealed the significance and adequacy of the ARDL model.

Table 4. Autoregressive Distributed Lag (ARDL) Model (1984-2017)

\section{Dependent Variable: D(LNRGDPPC)}

\begin{tabular}{|l|l|l|l|l|}
\hline Variable & Coefficient & Std. Error & t-Statistic & Probability \\
\hline C & 1.431401 & 0.380640 & 3.760512 & 0.0009 \\
\hline LNRGDPPC(-1)* & -0.132561 & 0.031724 & -4.178530 & 0.0003 \\
\hline LNINFR(-1) & 0.003496 & 0.010219 & 0.342082 & 0.7350 \\
\hline LNUNEMR(-1) & 0.057041 & 0.011033 & 5.170162 & 0.0000 \\
\hline LNINTR** & 0.036735 & 0.022851 & 1.607570 & 0.1200 \\
\hline D(LNINFR) & -0.013450 & 0.008534 & -1.576039 & 0.1271 \\
\hline D(LNUNEMR) & 0.011401 & 0.015930 & 0.715709 & 0.4805 \\
\hline LNINFR & 0.026370 & 0.075941 & 0.347237 & 0.7312 \\
\hline LNUNEMR & 0.430299 & 0.067876 & 6.339446 & 0.0000 \\
\hline LNINTR & 0.277118 & 0.188357 & 1.471239 & 0.1532 \\
\hline
\end{tabular}




\begin{tabular}{|l|l|l|}
\hline R-squared & 0.990494 \\
\hline $\begin{array}{l}\text { Adjusted R- } \\
\text { squared }\end{array}$ & & 0.988300 \\
\hline F-statistic & & 451.5096 \\
\hline Prob(F-statistic) & & 0.000000 \\
\hline
\end{tabular}

Source: authors' computation (2019).

\subsection{Autocorrelation (Breusch-Godfrey serial correlation LM) Test}

The Breusch-Godfrey serial correlation LM test shows the absence of serial correlation in the model as revealed by the result in table 5 below. The probability value of the F-Statistic confirms that the residuals were serially uncorrelated.

Table 5. Breusch-Godfrey Serial Correlation LM Test

\begin{tabular}{|c|c|c|c|}
\hline \multicolumn{4}{|c|}{ Null hypothesis: No serial correlation at up to 2 lags } \\
\hline F-statistic & 0.229309 & Prob. F(2,24) & 0.7968 \\
\hline Obs*R-squared & 0.618775 & Prob. Chi-Square(2) & 0.7339 \\
\hline
\end{tabular}

Source: authors' computation (2019).

\subsection{Normality Test for Residual (Histogram and Jarque-Bera) Test}

The probability value 0.65 which is greater than the 0.05 critical value for the jarque-bera test, gave a reasonable cause for the acceptance of the null hypothesis that the error term followed a normal distribution as shown in figure 2 below.

Fig 2. Histogram and Jarque-Bera Test For Residual 


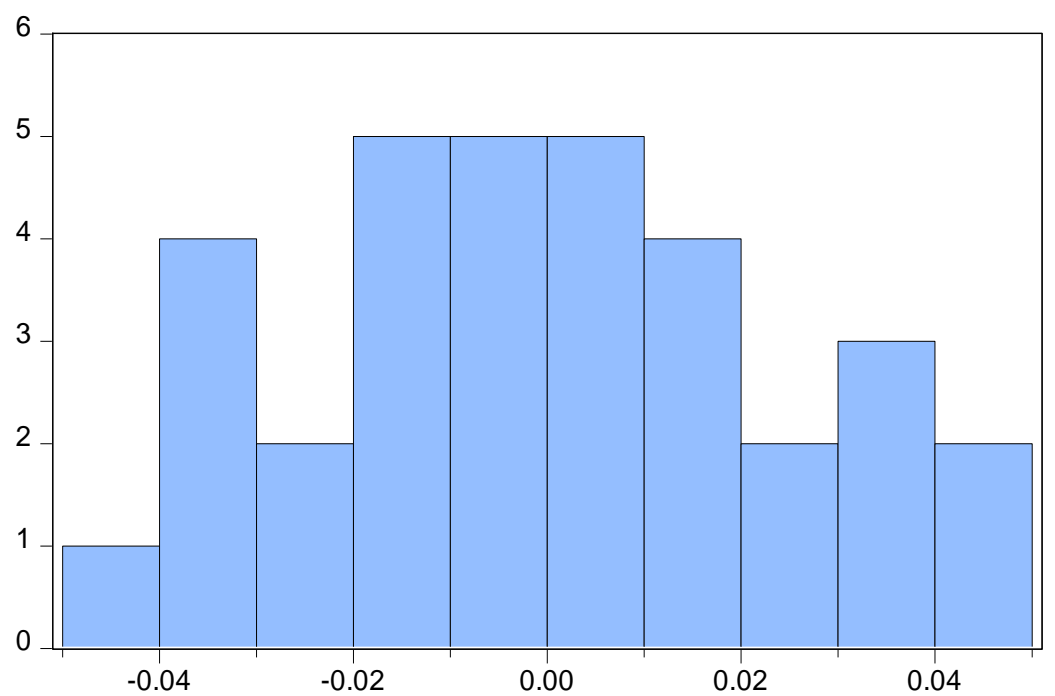

Series: Residuals

Sample 19852017

Observations 33

Mean

$-2.55 e-15$

Median

$-6.74 \mathrm{e}-05$

Maximum

0.045045

Minimum $\quad-0.046089$

Std. Dev. $\quad 0.023560$

Skewness $\quad 0.062953$

Kurtosis $\quad 2.217688$

Jarque-Bera $\quad 0.863312$

Probability $\quad 0.649433$

Source: authors' computation (2019)

\subsection{Stability Test (CUSUM Graph)}

The result from Figure 3 below obviously indicated that the model was stable until the period 1998 to 2001 which showed a bit of instability after the CUSUM line went beyond the 5\% significance line. The result is not desirable as the entirety of the sample period of the study is not stable.

Fig 3. Cumulative sum (CUSUM) Stability Test 


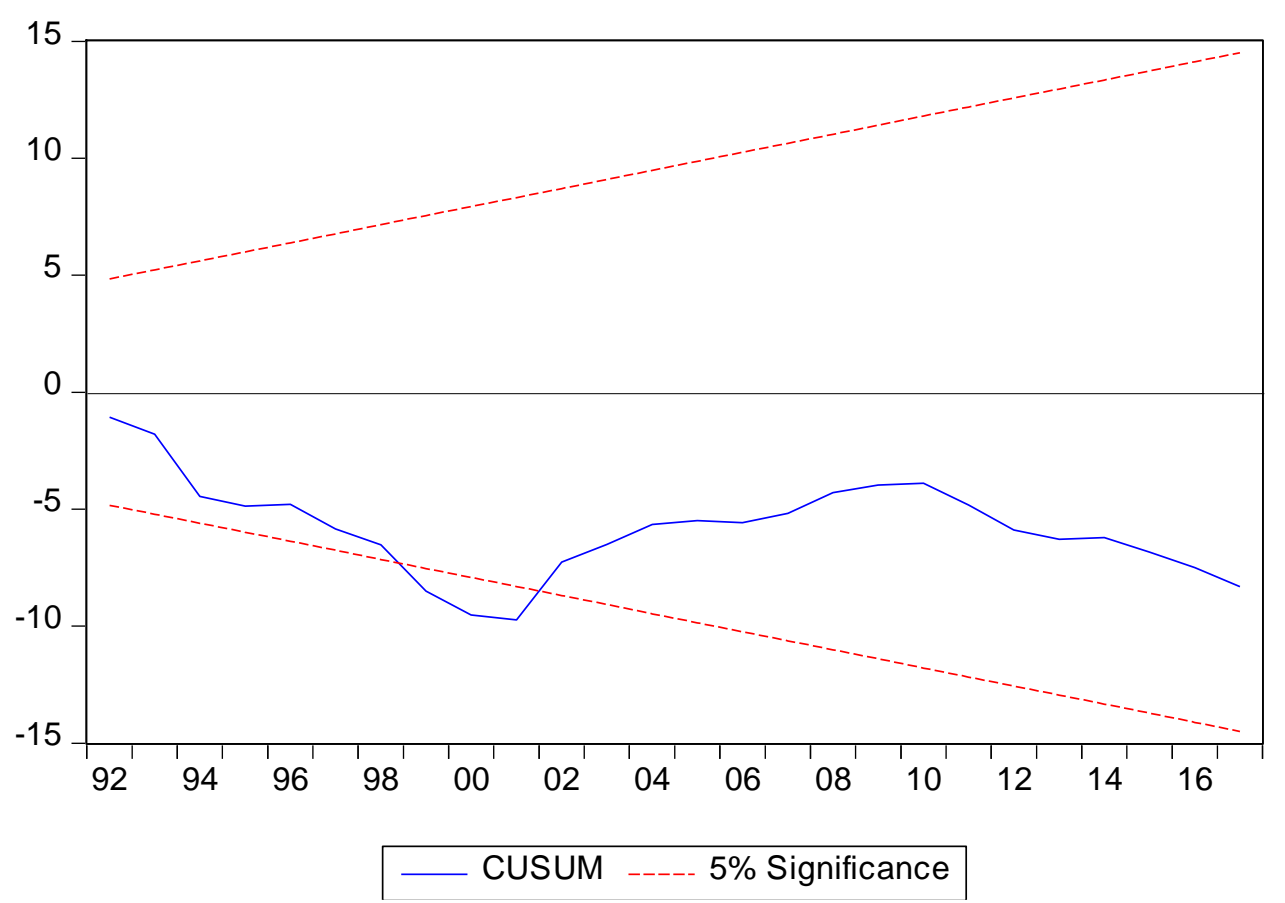

Source: authors' computation (2019)

\section{Conclusion and Recommendations}

The purpose of this study was to examine the effect of macroeconomic variables inflation rate (INFR), unemployment rate (UNEMR) and interest rate (INTR) on real gross domestic product per capita (RGDPPC) (proxy for economic growth) in Nigeria over the period 1984 - 2017 (34 years) using an ARDL model. Based on the findings, it was found that inflation rate had negative and insignificant effect on economic growth in the short-run and a positive and insignificant effect on the economic growth in the long-run in Nigeria. More so, coefficient of unemployment revealed a positive and insignificant impact on economic growth in the short-run and a positive and significant impact on economic growth in the long-run. The study also revealed a positive and insignificant effect of interest rate on economic growth in Nigeria in the long-run. The finding of this study is in accordance with the findings of Onwachukwu (2015), Kasidi and Mwakanemela (2013), Inyiama (2013), Akeju and Olanipekun (2014), Ezi (2014) and Ogueze and Odim (2015) who investigated the effect of inflation rate on economic growth in various countries, and found that inflation rate has negative impact on gross domestic product (GDP) of the countries studied; on the other hand, the finding of the study contradict the finding of Sweidan (2004) who also carried out similar research on the subject matter, and found that 
inflation had positive impact on the gross domestic product (GDP) in the country. Moreover to achieve an all inclusive economic growth in Nigeria, policies geared towards the increase in the level of output in other sectors of the economy with a labour intensive technique of production should be adopted. Policy makers should focus on maintaining inflation at a low rate (single digit), ensuring interest rate stability and improvement of the educational system with entrepreneurial skill acquisition curriculum so that young school leavers and the graduates alike would be more of job creators rather than job seekers. In conclusion, the use of ARDL in this study is a narrative to the subject area in Nigeria and it reveals the relationship among the variables under consideration in both the long-run and short-run. Future researchers may consider the use of ARDL modeling using quarterly or monthly data as more data becomes available.

\section{References}

Acha, A. V. (2011). An Overview of Monetary Policy Framework in Nigeria, CBN Bulletin, 33(1): 20-46.

Ademola, A. S. and Badiru, A. (2016). The impact of unemployment and inflation on economic Growth in Nigeria, International Journal of Business and Economic Sciences Applied Research, 9(1): 47-55.

Adenuga, I. A., Bello, H. T. and Ejumedia, P.E. (2012). “ Is inflation a purely monetary phenomenon? Empirical Investigation from Nigeria (1970-2009)” . European Scientific Journal, 8(17): 236-248.

Akeju, K. F. and Olanipekun, D. B. (2014). Unemployment and economic growth in Nigeria. Journal of Economics and Sustainable Development, 5(4): 138-144.

Altavilla, C. and Ciccarelli, M. (2009). “ The Effects of Monetary Policy on Unemployment Dynamics under Model Uncertainty: Evidence from the US and the Euro Area” . Europian Central Bank Working Paper Series No. 1089.

Aminu, U., Manu, D. and Salihu, M. (2013). An empirical investigation into the effect of unemployment and inflation on economic growth in Nigeria. Interdisciplinary Journal of Research in Business, 2 (12): 1-14.

Aminu, U. and Anono, A. Z. (2012). An empirical analysis of the relationship between unemployment and inflation in Nigeria: 1977-2009. Business Journal, Economics and Review, 1(12): 42-61.

Bakare, A. S. (2012). Stabilization Policy, Unemployment Crisis and Economic Growth in Nigeria. Universal Journal of Management and Social Sciences, 2(4): 55-63

Bhatti, M. I., Hossain, M. Z., and Al-Shanfari H. (2004). Model Selection in the context of 
Arbitrage Pricing Theory. Journal of Statistical Theory and applications, 3(1): 33-52. Engler, P. (2011). “ Monetary Policy and Unemployment in Open Economies” . NCER Working Paper Series, No. 77.

Essien, S. N., Manya, G. A., Arigo, M. O., Bassey, K. J., Ogunyinka, S. F., Ojegwo, D. G. and Ogbuehi, F. (2016). Monetary policy and unemployment in Nigeria: Is there a dynamic relationship? CBN Journal of Applied Statistics, 7(6): 209-231.

Ezi, B. I. (2014). Retired but not tired: Linking retirement and informality of labour. Asian Journal of Humanities and Social Sciences, 2(1): 37-46.

Fadayomi, T. O. (1992). Migration Development and Urbanization Policies in Sub-Saharan Africa, CODESRIA Books Series Ibadan pp 27-30

Feridun, M. and Akindele, S.T. (2006). “ The crux of the matter, in Nigeria Economy: essays on economic development ed. (Feridun and Akindele)" . Munich Personal RePEC Archive. $M P R A,: 1-13$

Folorunso, B. A. and Abiola, A. G. (2000). “Longrun Determinants of Inflation in Nigeria (19701998)" . Nigeria Journal Economics \& Social Studies, 42(1): 10-26.

Giles, D. (2013). ARDL Models - Part II- Bounds Tests. Available: https://davesgiles.blogspot.com/2013/06/ardl-models-part-ii-bounds-tests.html

Gujarati, D. N. (2004). Basic Econometrics. 4th Edition. The McGraw-Hill Companies. 2004.

Gujarati, D. N. (2005). Essentials of Econometrics. McGraw-Hill International Edition. 2005.

Inyiama, O. I. (2013). Does inflation weaken economic growth? Evidence from Nigeria.

European Journal of Accounting Auditing and Finance Research, 1(4): 139-150.

James, C., (2019) Inflation. Available: https://www.investopedia.com/terms/i/inflation.asp.

Jeffrey, M. W. (2012). Introductory Econometrics: A modern Approach. Fifth Edition.

Jelilov, G., Obasa, O. J., and Isik, A. (2016). The Impact of Inflation and Employment in Nigeria (2001-2013). Sacha Journal of Policy and Strategic Studies, 6(1): 28-34.

Jim, C., (2019). Gross Domestic Product. Available: https://www.investopedia.com/terms/g/gdp.asp

Jim, C. (2019). Per Capita GDP. Available: https://www.investopedia.com/terms/p/per-capita-gdp.asp

Jim, C. (2019). Economic Growth. Available: https://www.investopedia.com/terms/e/economicgrowth.asp

Kasidi, F. and Mwakanemela K. (2013), impact of Inflation on Economic Growth: A Case Study of Tanzania. Asian Journal of Empirical Research, 3(4): 363-380. http://aessweb.com/journal-detail.php?id=5004

Kitov, I., Kitov, O. (2011). Employment, unemployment and real economic growth. MPRA Paper 32404. https://mpra.ub.unimuenchen.de/32404/1/MPRA_paper_32404.pdf.

Kripfganz, S. and Schneider D. C. (2018). ARDL: Estimating Autoregressive Distributed lag and Equilibrium Correction Models. London Stata Conference, (September 7, 2018). Available: http://repec.org/usug2018/uk18_kriptganz.pdf 
Meyer, B. and Tasci, M. (2012). An unstable Okun's Law, not the best rule of thumb. Economic Commentary, 8, 1-5.

Mbulawa, S. (2015). "Effect of Macroeconomic Variables on Economic Growth in Botswana” , Journal of Economics and Sustainable Development, 6(4): 68-78.

Nihat, Ali, and Emrah. (2013). Last Review 15 August 2013, Analyzing Macroeconomic Indicators of Economic Growth Using Panel Data. Journal of Finance \& Investment Analysis, 16/2, No. 3: 41-53

Nkoro, E. and Uko, A. K. (2016). Autoregressive Distributed Lag (ARDL) Cointegration technique: Application and Interpretation. Journal of Statistical and Econometric Methods, 5(4): 63-91.

Ogueze, V. C., and Odim, O. K. (2015). The cost of Unemployment and its effects on GDP Growth in Nigeria. World Applied Science Journal, 33(1): 86-95.

Onwachukwu, C.I. (2015). Does Inflation Significantly Impact on Economic Growth in Nigeria? Global Journal of Human Social Science: Economics, 15(8) version 10.

Olawunmi and Adebayo. (2017). Unemployment \& Economic Growth in Nigeria in the $21^{\text {st }}$ Century: VAR Approach. AUD (E, 13(5): 155-168.

Available:https://journals.univdanubiz.ro/index.php/oeconomical/article/viewfile/4064/42 $\underline{56}$

Orji, A., Orji-Anthony, I., and Okafor, J. (2015). Inflation and Unemployment Nexus in Nigeria: Another test of the Phillip's Curve. Asian Economic and Financial Review, 5(5): 766-778.

Osinubi, (2006). The Political crisis and solution. Vanguard July 19.

Osuala, A. E., Osuala, K. I. and Onyeike, S. C. (2013). Impact of inflation on economic growth in Nigeria: A causality test. Retrieved from www.transcampus.org/journals; www.ajol.info/ journals/jorind, 11(1): 206-216.

Saymeh, A. A. and Orabi, M. (2013). The Effect of interest rate, inflation rate, GDP, on real economic growth rate in Jordan. Asian Economic and Financial Review, 3(3): 341-354.

Shrestha, B. and Bhatta G. R. (2018). Selecting appropriate methodological framework for timeseries data analysis. The Journal of Finance and Data science, 4(2): 71-89.

Sweidan, O. D. (2004). Does inflation harm economic growth in Jordan? An econometric analysis for the period 1970-2000. International Journal of Applied Econometrics and Quantitative Studies, 1(2): 41-66.

Thode, H. C. (2002). Statistics: textbooks and monographs, Vol. 164. Testing for normality. New York, NY, US: Marcel Dekker.

Udabah, S.I. (1999). Basic Economics Theory and Practice. Enugu, Linco Press Nigeria Limited

Umaru, A. and Zubairu, A. A. (2012). Effect of inflation on the growth and development of the Nigerian economy: an empirical analysis. International Journal of Business and Social Science, 3(10): 183-191. 